\begin{tabular}{|l|l|l||}
\hline \multicolumn{2}{|c|}{ PublisherInfo } \\
\hline \hline PublisherName & $:$ & BioMed Central \\
\hline \hline PublisherLocation & $:$ & London \\
\hline \hline PublisherImprintName & $:$ & BioMed Central \\
\hline \hline
\end{tabular}

\title{
Interfering with worms
}

\begin{tabular}{|l|l|l||}
\hline \multicolumn{2}{|c|}{ ArticleInfo } \\
\hline \hline ArticleID & $:$ & 3837 \\
\hline \hline ArticleDOI & $:$ & $10.1186 /$ gb-spotlight-20001120-02 \\
\hline \hline ArticleCitationID & $:$ & spotlight-20001120-02 \\
\hline \hline ArticleSequenceNumber & $:$ & 274 \\
\hline \hline ArticleCategory & $:$ & Research news \\
\hline \hline ArticleFirstPage & $:$ & 1 \\
\hline \hline ArticleLastPage & $:$ & 2 \\
\hline \hline & & RegistrationDate : 2000-11-20 \\
ArticleHistory & $:$ & OnlineDate $\quad$ 2000-11-20 \\
\hline \hline ArticleCopyright & $:$ & BioMed Central Ltd2000 \\
\hline \hline ArticleGrants & $:$ & \\
\hline \hline ArticleContext & $:$ & 130591111 \\
\hline \hline
\end{tabular}


William Wells

Email:wells@biotext.com

In the 16 November Nature, Fraser et al. and Gönczy et al. present the first large-scale reverse genetic analyses of a multicellular organism (Nature 2000, 408:325-330; Nature 2000, 408:331-336). Fraser et al. use RNA-mediated interference (RNAi) to target 2,416 predicted genes on chromosome I of the worm Caenorhabditis elegans by feeding the worms with bacteria expressing double-stranded RNA. Of the analyzed genes, $13.9 \%$ show a phenotype, increasing the number of sequenced chromosome I genes with a known phenotype from 70 to 378 . The identified genes include $90 \%$ of known embryonic lethal genes from chromosome I, but only $45 \%$ of genes with known post-embryonic phenotypes, with genes involved in nerve and sperm cell function apparently resistant to RNAi. The majority (60\%) of the phenotypes were embryonic lethal, including many genes involved in basic metabolism. The largest class of post-embryonic phenotypes are in the uncoordinated (Unc) class, which generally relate to neuromuscular function. Extrapolating from this screen, Fraser et al. estimate that the worm requires about 5,400 genes to live under standard laboratory conditions.

Gönczy et al. target 2232 genes from chromosome III using double-stranded RNA injected into worm gonads. They use time-lapse microscopy to look for any phenotype affecting cell division in the early worm embryo. There are 133 genes (around 6\%) that show a definite phenotype, suggesting that a total of over 1,000 worm genes are essential for the first two cleavage divisions. From the microscopic observations, the genes are grouped into classes involved in processes such as nuclear migration, cytokinesis and spindle positioning. Worm genes that have orthologs in both flies and yeast represent only $12.9 \%$ of genes tested, but they comprise $47.3 \%$ of those associated with a cell division phenotype.

\section{References}

1. Nature, [http://www.nature.com/nature/]

2. Potent and specific genetic interference by double-stranded RNA in Caenorhabditis elegans.

3. Specific interference by ingested dsRNA.

4. Genome-wide RNA-interference based screen for genes important in cell division, [http://mpiweb.embl-heidelberg.de/dbScreen/]

This PDF file was created after publication. 